\title{
Biopolítica y Propaganda Soviética: sobre el control del cuerpo en cinco carteles propagandísticos soviéticos contra el alcoholismo
}

\author{
Biopolitics and Soviet Propaganda: about the control of the body in five Soviet propaganda \\ posters against alcoholism
}

\author{
José Miguel Garay Rivera*
}

Resumen: Este ensayo presenta una reflexión en términos biopolíticos a partir del análisis a través del método iconográfico de Panofsky de cinco carteles propagandísticos soviéticos contra el alcoholismo que datan entre 1917 y 1990. La hipótesis principal es que, entre todos los objetivos al que pudiera apuntar una campaña gubernamental contra el alcoholismo, pareciera que la propaganda política soviética que abordó este tema lo hizo, en gran medida, cupabilizando y haciendo sentir vergüenza al consumidor de alcohol. Se presenta una discusión sobre estos objetivos y su relación con conceptos como tecnologías de poder y tecnologias del yo y, especialmente, de su intersección donde se da lo que Michel Foucault llama gubernamentalidad, y se describe su importancia en la constitución de los sujetos que se buscaba mediante el control político del cuerpo (biopolítica) en la hoy disuelta URSS.

Palabras clave: Biopolítica; propaganda política; gubernamentalidad; cuerpo; alcoholismo.

\begin{abstract}
This essay presents a reflection in biopolitical terms from the analysis -through Panofsky's iconographic method- of five Soviet Propaganda Posters against alcoholism dating from 1917 to 1990 . The main hypothesis is that among all the objectives that a government campaign against alcoholism can have, the Soviet Propaganda tried to make people feel guilty and ashamed. Finally, a discussion is presented about these objectives of the Soviet propaganda and its relation with concepts like such as power technologies and technologies of the self and especially its intersection that Michel Foucault calls governmentality, and is described its importance in the constitution of subjects that it was sought through the political control of the body (biopolitics) in the now dissolved USSR.
\end{abstract}

Keywords: Biopolitics; political propaganda; governmentality; body; alcoholism.

Recibido: 11 marzo 2019 Aceptado: 28 mayo 2019

\footnotetext{
* Chileno, autor principal. Doctorante en Teoría Crítica y Sociedad Actual por la Universidad Andrés Bello, Chile. Psicólogo por la Universidad de La Serena, Chile. Correspondencia: psi.garayrivera@gmail.com
}

Modalidad de publicación continua / Continuous publication modality 


\section{Introducción}

Este trabajo tiene por objetivo realizar un análisis y una posterior reflexión a partir de cinco carteles de propaganda política soviética enfocados a combatir el alcoholismo en el país entre 1917 y 1990. ${ }^{1}$ Para ello se hará un repaso condensado de las generalidades, ideas y principios más relevantes de la propaganda política, su desarrollo y papel protagónico en la historia de la política y de cómo se relaciona con el control de masas, para luego presentar un cuestionamiento sobre el eventual objetivo de la propaganda soviética contra el alcoholismo bajo la lupa del pensamiento de Michel Foucault, es decir, se pensarán conceptos como las tecnologías del yo, las tecnologías de poder, gubernamentalidad y, por sobre todo, biopolítica, generando así un marco de referencia lo suficientemente amplio para poder atender al análisis de la hipótesis principal que se desprende del examen de los carteles, a saber: que al menos una parte de la propaganda política soviética contra el alcoholismo estaba dirigida a causar dos emociones particulares en los consumidores: culpa y vergüenza, y mediante ellas ejercer un control del cuerpo para dejar de beber.

En términos generales, la noción de biopolitica de Michel Foucault servirá para poder guiar la reflexión sobre la cartelería seleccionada, mas no para el análisis propiamente tal de las imágenes, pues para esto último se hace necesario un método, especialmente si lo que se busca es dar un tratamiento al material visual que permita generar conocimientos a partir de él, o como diría Peter Burke, que no se utilice la imagen solo para ilustrar las conclusiones a las que el autor ya ha llegado por otros medios. ${ }^{2}$ Es por esto que, en la sección referente al método de este trabajo, se expondrá de forma específica cómo se realizó el análisis de los cinco carteles propagandísticos, el porqué de esa elección y otros aspectos relevantes como la traducción de la información del ruso al castellano.

Sin embargo, como el objetivo de este ensayo es presentar una reflexión teórica novedosa y crítica sobre lo hallado en la cartelería y no una generalización de resultados en base a un trabajo empírico, se determinó que con el tratamiento de cinco carteles propagandísticos era suficiente para plantear una discusión moderna de un tema ya muy revisado como la propaganda soviética. Por lo que queda hecha la invitación a quien desee, en base a un tratamiento de un corpus suficientemente abundante, hacer una generalización de los resultados. No es este el caso.

Finalmente, se plantea que al tener estas emociones como objetivo de la propaganda (culpa y vergüenza), lo que se buscaba era establecer un determinado control sobre el cuerpo del ciudadano soviético, especialmente del hombre en edad productiva, es decir, adulto y adulto joven (biopolítica), esperando lograr cierta auto-conducción de los sujetos que los alejara del consumo de alcohol (gubernamentalidad), para así, seguramente, poder prestar servicios útiles a la nación que vivía años de importantes reestructuraciones post-revolución bolchevique y que necesitaba de abundante mano de obra. Idea que será presentada y debatida en la parte final de este texto.

Hay que hacer, sin embargo, una salvedad. No son pocos los autores que han relacionado o admiten la relación entre gubernamentalidad y neoliberalismo o capitalismo, empezando por el propio Michel Foucault: "el control de la sociedad sobre los individuos no sólo se efectúa mediante la conciencia o por la ideología, sino también en el cuerpo y con el cuerpo. Para la sociedad capitalista es lo bio-político lo que importa, ante todo, lo biológico, lo somático, lo corporal. El cuerpo es una entidad biopolítica". ${ }^{3}$

\footnotetext{
${ }^{1}$ Las fechas que delimitan el periodo elegido responden a la duración histórica de la Rusia Soviética, es decir, desde la revolución rusa de 1917 hasta la desintegración de la URSS en 1990. Por ende, los carteles propagandísticos seleccionados debían comprender fechas de elaboración dentro de este periodo, siendo el más antiguo de los seleccionados de 1929 y el último de 1963.

2 Peter Burke, Lo visto y no visto. El uso de las imágenes como documento histórico., Barcelona, Ed. Biblioteca de Bolsillo, 2005.

${ }_{3}^{3}$ Michel Foucault, Conferencia El nacimiento de la medicina social, Revista centroamericana de Ciencias de la Salud (1977), Citado por Jorge Martínez, \& Yudi Guarín, Aproximación a una cartografía conceptual de la biopolítica. Revista Latinoamericana de Bioética, 2014, vol 14, No. 2, p. 102. Otros textos de Foucault donde se refiere explícitamente a esta relación son: Foucault, Vigilary Castigar... (1976); El sujeto y el poder (1988); Defender la Sociedad (2000); Nacimiento de la Biopolítica (2007).
} 
Esto empuja a que hacer un análisis foucaultiano de la gubernamentalidad en contextos socialistas, revista no solo una novedad, sino también una forma de entender que, en tanto sistema de producción, se interesa de igual manera por el cuerpo de los trabajadores, quizás no para acumular capital desde una clase dominante, pero sí -y del mismo modo que el capitalismo- para generar mano de obra productiva que acelere la edificación de la nación pensada por el socialismo.

\section{Marco Teórico}

\section{La propaganda política}

Sánchez en su tesis doctoral sobre la propaganda cultural soviética, dice rastrear el origen de la propaganda como objeto de estudio académico en los estudios políticos y sociales a partir de la Primera Guerra Mundial, donde además se fue dotando de una profunda connotación negativa. ${ }^{4}$ En cuanto al origen de la propaganda en sí misma, Ruiz señala que a partir de la Primera Guerra Mundial y sobre todo tras la revolución rusa, nacerá lo que hoy conocemos como cartel político o de propaganda. ${ }^{5} \mathrm{Y}$ esta aparición será sustentada por la naciente necesidad de movilizar a las masas, lo que antes no ocurría porque la actividad política y sus manifestaciones estaban confinadas a una pequeña élite cultural y económica.

Lo cierto es que tal y como señalan Jara \& Rojas, "la propaganda política es tan vieja como la política misma", y con toda seguridad existió en todos los países europeos beligerantes. En efecto, los mismos autores hacen un recorrido histórico interesante de la propaganda política deteniéndose en sus primeras expresiones surgidas en Creta, en la antigua Roma, en las antiguas culturas cristianas y en la Edad Media; pasando por la Revolución Francesa, Napoleón y su imperio, hasta llegar a la Revolución Rusa y el ascenso Nazi. Evidentemente el recuento de los autores señalados es mucho más acucioso, pero para efectos prácticos, sirve el haber llegado a un momento histórico que será clave en esta reflexión, la revolución de octubre de 1917 en Rusia.

De hecho, otros autores, tanto recientes como pasados, ${ }^{7}$ concuerdan con que la aparición de la propaganda en el contexto ruso de revolución (1917) y junto a la aparición de la figura de Lenin, marcarían un antes y un después en la historia del cartel o propaganda política, elevándola al status que tiene hoy vigente. Tal es el grado de importancia que Jara \& Rojas afirman que después de -y gracias a- la revolución rusa, la propaganda política se puede dividir en dos tipos claramente definidos, la propaganda persuasiva y la propaganda emocional. En palabras de los autores, "el tipo emocional de propaganda estaba destinado a influir, a inflamar, a empujar a las multitudes y a las masas a ejecutar los actos necesarios para defender y consolidar el "nuevo régimen". 8

Para profundizar esta idea, se puede señalar que el agrupar distintamente la propaganda, presupone, también, dos categorías diferentes de individuos a influenciar. Para los autores señalados, el punto de partida para hacer esta diferencia reside "en el hecho que todos los hombres no experimentan en modo alguno una misma reacción frente a la sugestión". 9 Sin embargo, las posibilidades no serían tan amplias. O bien se es susceptible a la sugestión o bien se es resistente. La propaganda de tipo persuasiva,

\footnotetext{
4 Ana Sánchez, La propaganda "cultural" soviética en la Segunda Guerra Mundial: los casos del comité para los asuntos de las artes y literatúrnaya gazeta (Tesis Doctoral). Universidad Pompeu Fabra, Barcelona, 2016.

5 Pilar Ruiz, El nacimiento del cartel político y su relación con las vanguardias. Questiones Publicitarias, 1997, No. (6), p.63-72.

${ }^{6}$ Lillyan Jara \& Pedro Rojas, La propaganda política. Santiago, Chile, Editorial Universitaria, 1956, 208 pgs.

${ }^{7}$ Consultar, por ejemplo, Jean-Marie Domenach, La propaganda política (1950); Inmaculada Julián, La propaganda Rusa en el periodo 1917-192 (1986); Guilherme Luthmeier, A propaganda politica soviética... (2010); Jessica Petrino, La propaganda del movimiento bolchevique (2016).

8 Jara y Rojas, op.cit., 52.

${ }^{9}$ Jara y Rojas, op. cit., 94.
} 
que también será llamada propaganda racional, estará enfocada al grupo que los autores llaman "resistentes". Mientras que, evidentemente, la emocional estará destinada para los sugestionables, donde lo que se busca es "actuar sobre los sentidos (...) con el objetivo de provocar emociones capaces de impresionar a las muchedumbres, de atemorizarlas y de despertar entusiasmo entre partidarios". ${ }^{10}$

Otro aspecto fundamental para la propaganda política de la que no se puede no hacer repaso, tiene que ver con el importante trabajo de quien es, quizás, el responsable de que el ejercicio propagandístico fuese prácticamente una disciplina, incluso cercana al arte: Paul Joseph Goebbels, político alemán y Ministro para la Ilustración Pública y Propaganda del Tercer Reich entre 1933 y 1945.

Sus llamados Principios de la propaganda, o también leyes de la propaganda, abrirán a éste como un campo de profundo interés académico, concentrando gran parte de la literatura científica de posguerra. La precisión con que expuso sus reglas y, sobre todo, la macabra eficacia con la que funcionan, lo hacen acreedor de un repaso obligado si se pretende navegar por las aguas que él hiciera (tristemente)célebres.

\section{Los principios de la Propaganda de Goebbels:}

- Regla de la simplificación y de la concentración: La simplificación trata de dividir y definir la doctrina y argumentos de la manera más clara posible. Se busca definir al adversario o líder político opositor. Se tranquiliza así a los otros partidarios, seguros de tener enfrente no una masa resuelta como ellos sino una multitud engañada.

- Regla de la exageración y desfiguración: La exageración de las noticias para resaltar toda información que sea favorable o desfavorable para el otro bando.

- Ley de la repetición y orquestación: La repetición incesante en diferentes formatos y presentaciones de los temas principales es un elemento esencial para la propaganda. Siempre se debe de adaptar muy bien el tono y la argumentación a los diferentes públicos.

- Ley de la transfusión o compenetración: Es el uso de la convicción conectando con los nuevos estereotipos ya existentes en la sociedad. Se intenta así conectar con el público directamente para después hacerles llegar el mensaje.

- Ley de unanimidad y del contagio: La propaganda deberá crear y reforzar la unanimidad de las masas y así contagiarla rápidamente, una buena manera de lograrlo es a través de manifestaciones o desfiles". 11

\section{Propaganda y manipulación de masas}

Por neutro que se le suponga, el individuo en muchedumbre se encuentra en un estado de 'atención expectante' que hace fácil la sugestión, y, como en todos los seres

sugestionados, la idea que se apodere de su cerebro tiende a transformarse en acto Le Bon, 1952 (en Jara \& Rojas, 1956, p.79)

Es poco probable que la propaganda de por sí sea capaz de contener en su interior ese inmenso poder de dominación de un pueblo. Es la complicidad de ciertas disciplinas las que le otorgan esta capacidad. Dichas disciplinas son la psicología en mayor medida y la sociología en menor parte. La propaganda sin el influjo de la psicología no habría llegado a ser propaganda como la entendemos hoy. Existe relativo consenso en cuanto a que la identidad de los sujetos está sujeta a como se

10 Jara y Rojas, op. cit., 97.

11 Jara y Rojas, op. cit., 118-146. 
transforma/domina por sí mismo y por presión de las estructuras de poder. Es decir, a cómo se piensa él mismo en un contexto determinado. ${ }^{12}$ Esto no es posible sino gracias a la psicología.

Más de una vez tuve en mi juventud ocasión de darme cuenta y penetrar instintivamente la enorme significación psicológica que entrañan los símbolos. Después de la guerra asistí en Berlín a un mitin marxista delante del Palacio Real, en Lustgarten. Un mar de banderas rojas, de brazaletes rojos y de flores rojas daba a esta demostración, aproximadamente de ciento veinte mil personas, un aspecto exterior imponente, y yo mismo sentía y comprendía la facilidad con que el hombre del pueblo se deja dominar por la magia seductora de un espectáculo de tan grandiosa apariencia. ${ }^{13}$

Si la propaganda quiere ser efectiva y entrar en el subjetivo del cuerpo social, como lo relata Hitler, deberá siempre atender a las creencias, los valores y las costumbres del público objetivo, y por ende la psicología, en tanto discurso de las emociones que llega a la opinión pública, comparte una complicidad enorme con los métodos de subjetivación de los distintos sistemas políticos. Por ejemplo, en sociedades de mercado, se ha llegado a posicionar a la publicidad como una nueva religión, ${ }^{14}$ permitiéndole dotar de simbolismos y valores imaginarios a objetos comunes.

En efecto, según Jara \& Rojas, las dos fuentes de la propaganda política son, de hecho, la publicidad y la ideología política. Para los autores, que siguen muy de cerca las ideas de Domenach, la propaganda y la publicidad evolucionan de forma paralela. "A la marca de auto, el símbolo; al slogan comercial, la consigna política; parece más bien que la propaganda es la que se inspira en los métodos publicitarios, copiando su estilo y formas de agradar al público". 15

El lingüista norteamericano Noam Chomsky, ha sido uno de los intelectuales contemporáneos que más tiempo le ha dedicado al tema de la manipulación de masas. ${ }^{16}$ A partir de su amplio trabajo sobre la temática, el investigador francés Sylvain Timsit escribiría Stratégies de manipulation, un pequeño texto donde formula en base a las ideas de Chomsky las "10 estrategias de manipulación"17 a través de los medios de comunicación, que sirven hoy para ilustrar, junto a los principios de Goebbels, los métodos de la propaganda:

1. La estrategia de la distracción: desviar la atención del público de los problemas que son importantes mediante un bombardeo de información para distraer y tapar lo realmente importante.

2. Crear problemas y después ofrecer soluciones: se crea un problema concreto en la sociedad para así conseguir una reacción por parte de la población.

3. La estrategia de la gradualidad: ir aplicando esta estrategia, poco a poco, durante años, para así no incitar a una gran revolución.

4. La estrategia de diferir.

5. Dirigirse al público como criaturas de poca edad.

6. Utilizar el aspecto emocional mucho más que la reflexión. Técnica clásica para neutralizar el sentido crítico de la población.

7. Mantener al pueblo en la ignorancia y la mediocridad.

\footnotetext{
12 Para más precisión sobre esta idea, consultar: Foucault, Vigilary Castigar... (1976); Tecnologías del yo y otros textos afines (1990); Nacimiento de la Biopolitica (2007).

13 Adolf Hitler, Mi lucha, Santiago, Galas Ediciones, 2012, p.292

${ }_{14}$ Juan Rey, Publicidad y religión. Semejanzas y diferencias entre el discurso publicitario y el discurso católico. Trípodos, 2006, Vol 1, No (18), p. 65-94.

15 Jara y Rojas, op. cit., 99.

16 Consultar, por ejemplo: Noam Chomsky, El miedo a la democracia (1992a); Ilusiones necesarias... (1992b); La propaganda y la opinión pública (2002).

${ }^{17}$ Sylvain Timsit, 10 estrategias de manipulación (2002), online http://www.syti.net/ES/Manipulations.html
} 
8. Estimular al público a ser complaciente con la mediocridad. Despreciar lo intelectual, poner de moda la mediocridad.

9. Reforzar la autoculpabilidad.

10. Conocer a los individuos mejor de lo que ellos se conocen a sí mismos.

\section{Sobre la propaganda política como material visual}

Para Peter Burke tanto el Nacional Socialismo como el Socialismo Soviético son relativamente fáciles de expresar en imágenes, "tanto si éstas caricaturizan a los extranjeros, como si celebran los grandes acontecimientos de la historia nacional". ${ }^{18}$ Lo interesante es enfrentarse a la propaganda política entendiendo que, "tanto el grado en el que los gobiernos utilizan las imágenes como el modo en que lo hacen varía considerablemente de una época a otra". ${ }^{19}$ Además, el autor británico introduce el tema de la propaganda como material visual advirtiendo sobre su importante uso de figuras retóricas, especialmente la metáfora, que en sus palabras: "junto al símbolo han desempeñado siempre un papel importante en política". ${ }^{20}$ Una metáfora tradicional de las distintas propagandas políticas -dice Burke-, es la de la nave del estado, en la que el gobernante o su primer ministro ejercen la función de piloto. O la de gobierno como caballo y el jinete, donde se desarrolla la idea de domar el potro del poder o de tomar las riendas de la política. Como veremos más adelante, esto último es de suma importancia en este caso específico, pues el método que se empleó proviene de las ideas de Erwin Panofsky, pero con un especial énfasis en la detección de figuras retóricas.

\section{Apuntes sobre la historia del alcohol en Rusia}

Si algo se puede establecer con certeza, es que el uso político y el consumo recreativo de alcohol en Rusia ha sido presa de vaivenes y administraciones confusas desde la época de los zares hasta, incluso, la actualidad. En efecto, se considera que desde Pedro el grande, Zar de todas las Rusia desde 1682 hasta 1725, el alcohol comenzó a ser tema recurrente para los gobernadores. Él, en su caso, "generó la idea de explotar la producción a nivel artesanal de sal, vodka y algunos metales, generando un monopolio que le permitiera tener ventaja de cara a transacciones exteriores". ${ }^{21}$ Esta visión sobre el alcohol, sin embargo, se mantuvo constante durante largos años, y no sólo en el periodo de Pedro el grande.

Empero, constancia no significa ausencia de problemas. Ya en la decadencia del zarismo, los últimos gobernantes comenzaron a mostrar preocupación por el efecto negativo de siglos promoviendo la elaboración incesante de alcohol. Comenzaron a aparecer las llamadas casas populares, que vendrían siendo una especie de centros culturales masivos, que en palabras de Millar:

Tenían por objetivo principal promover la sobriedad entre las clases bajas ofreciéndoles "recreaciones racionales" en forma de representaciones teatrales, conferencias, salas de lectura, excursiones y otras actividades que prescindieran del alcohol. Aunque su impacto en el consumo popular de alcohol es dudoso, las casas populares ofrecían a la gente común oportunidades educativas modestas y una variedad diversa de entretenimientos teatrales asequibles. ${ }^{22}$

Esta medida, que parece acertada al sentido común, guarda tras de sí el anhelo del zar de no cesar la producción y el monopolio mundial del vodka y solo paliar o preocuparse parcialmente de los efectos

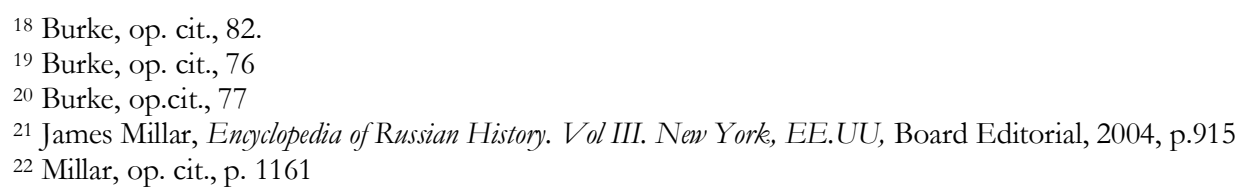


negativos. De hecho, en 1890 pasa a ser auspiciado por el ministerio de finanzas y se incluyen los impuestos a la compraventa interna, lo que reafirma una clara voluntad política de continuar con producción de alcohol.

La primera guerra mundial llegaría para cambiar este escenario, profundizando la necesidad de tener a la ciudadanía sobria, se decretará en 1914 una prohibición masiva de alcohol por parte del zar. Ya en 1917, con el ascenso bolchevique y la eliminación del sistema zarista, el gobierno soviético ratificaría el aporte de las casas populares, que pasarían a llamarse "palacios de cultura" y "clubes de trabajadores". Sin embargo, y para sorpresa de muchos, pero motivados por la crisis económica a la que entraba la URSS en comparación a su competencia occidental industrializada y capitalista, en 1923-1924 el gobierno equilibraría su presupuesto, introduciendo impuestos a las propiedades, cobrando tarifas escolares y reintroduciendo el monopolio del vodka. ${ }^{23}$

Existía entonces un Estado que promovía la elaboración de vodka para desarrollar la economía, pero que sabía el daño y los efectos negativos que eso conllevaba, lo que los llevaba a mantener las acciones paliativas de los efectos del alcoholismo, tal es el caso de la propaganda y de las campañas antialcohol que serán objeto de reflexión en este trabajo.

Culturalmente hablando, Millar también aporta referencias que pueden ser útiles para poder dar con un significado realmente profundo en el análisis de la cartelería, y es que las costumbres alimenticias y los simbolismos que rodean la comida en Rusia también han marcado la cuestión sobre el alcoholismo. El autor señala, por ejemplo, que en las ceremonias como cumpleaños, bodas, aniversarios o incluso feriados importantes, se hacían grandes celebraciones donde las mesas estaban repletas de quesos, alimentos encurtidos, papas y repollos, así como también de vodka y vino que se bebía durante toda la fiesta, que solían ser largas. De esta forma, algunos alimentos adquirían reales significados inmateriales, por ejemplo "el pan era el símbolo de la vida; otros alimentos como el caviar, significaban lujo; setas y bayas, los regalos del bosque; la papa, símbolo de la supervivencia en tiempos difíciles, y el vodka, que simboliza camaradería y travesuras". ${ }^{24}$

\section{Biopolítica: gubernamentalidad y otros conceptos}

Relacionar la vida, el cuerpo y la política es un terreno del ejercicio académico que le debe su productividad, en gran parte, a Michel Foucault, quien entre sus clases en el Collège de France y sus distintos textos y conferencias, comenzó a plantear juntos conceptos como la vida, la política, el cuerpo, la población, la seguridad, entre otros, que fueron dando forma a lo que se conoce como biopolítica.

La idea es que aquel poder que irrumpía en la Edad Media como absoluto, disciplinador y normalizador de los individuos mediante un efecto directo sobre ellos (castigo, encarcelamiento, expulsión, tortura, por ejemplo), fue paulatinamente convirtiéndose en una política sobre la vida misma, siendo el cuerpo individual, pero sobre todo el cuerpo social, objetos donde la política ejercerá el poder pero ya no necesariamente como disciplina directa sobre los individuos, sino que también mediante la autorregulación y la autodominación de los propios sujetos sobre sí mismos.

La biopolítica no es esa forma de poder que actúa directamente sobre los cuerpos de los sujetos para producir individuos dóciles, tal y como era propio el proceder de la anatomo-política en los regímenes disciplinarios. A la población se la controla ahora de otro modo distinto. Los mecanismos de control ya no van enfocados al cuerpo individual, sino a un cuerpo social. ${ }^{25}$

\footnotetext{
23 Millar, op. cit., p. 1041

24 Millar, op. cit., p. 1362

25 Silvio Gallo, Filosofía, enseñanza y sociedad de control, 2010 cit. en Geo Saura \& Julian Luengo, Biopolitica y educación. medición, estandarización, regularización poblacional, Teor. educ., 2015, Vol 27, No.(2), p.115-135.
} 
Es decir, por un lado tenemos lo que Foucault llamó tecnología de poder, esto es: un poder que se ejerce desde el exterior, que se impone, domina y objetiviza al sujeto desde "arriba". ${ }^{26}$ Y por otro lado tenemos las tecnologías delyo, que son aquellos procesos por los cuales el sujeto lleva a cabo una dominación sobre sí mismo. Lo que da paso, además, al concepto de gubernamentalidad, es decir, aquel espacio o intersección en donde los sujetos se constituyen tanto por la acción de las tecnologías del poder, como por la acción de las tecnologías del yo. ${ }^{27}$

Por ende, el otrora poder que ejerciera el soberano se convierte entonces en biopolítica: forma de regulación de la vida y del cuerpo individual y social. "Es un poder que se ejerce positivamente sobre la vida, que procura administrarla, aumentarla, multiplicarla, ejercer sobre ella controles precisos y regulaciones generales". 28 "Es un control del cuerpo de la población como especie mediante mecanismos de regulación". ${ }^{29}$ En definitiva, entre la gubernamentalidad y la biopolitica, lo que se busca es la absoluta desaparición de todo espacio ingobernable de la vida. Para Foucault este análisis sería más sencillo pensando al capitalismo como contexto, donde:

El ajuste entre la acumulación de los hombres y la del capital, la articulación entre el crecimiento de los grupos humanos y la expansión de las fuerzas productivas y la repartición diferencial de la ganancia, en parte fueron posibles gracias al ejercicio del bio-poder en sus formas y procedimientos múltiples". ${ }^{30}$

Pero eso no nos limita para pensar el contexto soviético como un símil que, si bien no buscaba la generación de riquezas a través de la explotación y la enajenación de la clase obrera, si debió potenciar un masivo éxodo de campesinos a las ciudades y emplearlos en a las industrias, pues se encontraban en 'desventaja' con aquellas naciones occidentales que comenzaron paulatinamente a entrar a fases de producción industriales derivadas del capitalismo. De esta forma, se estaría frente a un poder que se ejerce de igual manera sobre la vida misma del trabajador, intentando aumentar su propia productividad y eficacia, tal como en el capitalismo.

Parafraseando a Martínez \& Guarín, se podría decir que al biopoder le interesa el cuerpo de los trabajadores, y por eso la vida se sitúa como el centro del debate y de las gestiones e intervenciones del Estado y del mercado, en cuanto el trabajador es la fuerza productiva que mantiene el sistema. ${ }^{31} \mathrm{O}$ como lo dirían Hardt y Negri, "las sociedades de control se basan en el poder que se difunde en todos los cuerpos, y que buscan aumentar la productividad, donde el individuo es invadido por los medios y el poder". 32

El cuidado de la población pasa entonces a implicar una focalización de la acción de los gobiernos sobre los aspectos biológicos de la vida: los cuerpos, sus enfermedades, nacimientos, [vicios] $]^{33}$, muertes, distribución territorial, por ejemplo. (...) En definitiva, el Estado debe ocuparse de los cuerpos de los ciudadanos, ya sea para ayudarlos con sus problemas de salud y enfermedad mediante los sistemas de salud pública o ya sea para exigir de ellos ciertas prácticas. ${ }^{34}$

\footnotetext{
${ }^{26}$ Consultar Foucault, Vigilary Castigar... (1976).

27 Michel Foucault, Tecnologias del yo y otros textos afines, Buenos Aires, Argentina, Ediciones Paidós, 1990.

${ }^{28}$ Foucault, Vigilary Castigar..., 1976, p. 165

${ }^{29}$ Foucault, op. cit., p. 168.

${ }^{30}$ Foucault, op. cit., p. 171.

31 Martínez y Guarín, op. cit., xx

32 Michael Hardt \& Antonio Nergi, Imperio, 2014, citados en Martínez y Guarín, Aproximaciones a una cartografia..., 2015 , p. 116.

${ }_{33}$ Los corchetes son míos

34 Jorge Martínez, El cuerpo como nueva superficie de inscripción de la política: Michel Foucault y la biopolítica., Revista Sociología y Tecnología, 2017, Vol 8, No (1), p.27-42.
} 
No es sorpresa entonces que a pesar de no ser un disciplinamiento directo sobre el cuerpo, como lo era el castigo o el encarcelamiento, el biopoder siga buscando el control del cuerpo social a partir del control del cuerpo individual, ahora con otros métodos: las ya señaladas tecnologías del yo, que ejercen una autodominación de los sujetos sobre sí mismos que implica ciertas formas de aprendizaje y modificación de los individuos que van más allá de la evidente adquisición de nuevas habilidades, sino que es, además, una adquisición de ciertas actitudes. Lo que para Foucault significa un cambio en el ethos mismo de la persona, en su forma de ser y pensarse. ${ }^{35}$ Es un modo de subjetivación, de constitución de sujetos útiles para un determinado contexto.

De este modo, se puede pensar que el objetivo de la biopolítica es la vida y el cuerpo social o población, y que para ello recurrirá a la autorregulación del cuerpo mismo. En ese marco, dirá Foucault "el poder no busca (...) mostrarse en su plenitud como un derecho de matar como defensa contra las ofensas que se le infringen, sino que se propone invadir la vida enteramente". ${ }^{36}$

Tenemos un contexto donde, finalmente, el cuerpo individual y el cuerpo social son manipulados, regulados y gobernados por ser precisamente el sustrato de la capacidad laboral. Esta regulación lleva a cabo dominaciones que pueden o no ser directas, siendo de hecho más frecuente que sean indirectas, es decir, el mismo individuo sobre sí, generando una especie de ajuste de los cuerpos individuales y sociales que ponen en marcha los requerimientos normalmente económicos de los gobiernos.

\section{Método}

Sabemos que una imagen es "necesariamente explícita en temas que los textos pueden pasar por alto fácilmente. Es un valioso testimonio de otros aspectos de la praxis social, a menudo no documentados por ningún otro vestigio". ${ }^{37}$ Lo que ésta en discusión, más bien, es cómo tratar correctamente las imágenes. No es menos cierto que la imagen se usa en distintos contextos académicos, pero el cómo se emplea -en la mayoría de los casos- está lejos de ser un tratamiento acorde para generar conocimiento.

Como diría Gaskell ${ }^{38}$ para no parecer "ingenuos y triviales" frente a la cartelería política, ni terminar usando la propaganda solo de acompañamiento de una idea que proviene de otras partes y no del análisis de las imágenes en sí, este ensayo intentó nutrirse de un método que fuese lo más riguroso posible y nos permita así teorizar a partir de los carteles y no sobre $e^{39}$ los carteles. Sin embargo, como ya se advirtió en un comienzo, el objetivo de este texto es plantear una reflexión teórica moderna sobre la propaganda política soviética, no elaborar una investigación empírica a partir de los carteles. Esto no es motivo, sin embargo, para no darle un tratamiento riguroso a las imágenes seleccionadas.

El método utilizado se desprendió de una adaptación del método iconográfico e iconológico de Erwin Panofsky. ${ }^{40}$ Esto quiere decir que cada cartel propagandístico fue analizado, en parte, atendiendo a aspectos sugerido por los tres niveles de Panofsky:

1. Pre-iconográfico, que se basa en describir los elementos, lo que se encuentra a simple vista. Es el reconocimiento.

\footnotetext{
35 Foucault, Tecnologías del yo..., (1990).

36 Foucault, La voluntad de saber. México DF,: Siglo XXI, 1996, p.169.

37 Lourdes Roca, La imagen como fuente: una construcción de la investigación social. Revista Razón y Palabra, 2004, No. (37), p. 2.

38 Ivan Gaskell, Historia de las imágenes, 1993, pp. 209-239., En Peter Burke. (Ed.), Formas de hacer historia, Madrid, Alianza Universidad, 1993.

39 Entiéndase sobre como "por encima de ellos", es decir, sólo como mero acompañamiento.

${ }^{40}$ Erwin Panofsky, El significado en las artes visuales. Madrid, España: Alianza Forma, 1979.
} 
2. Iconográfico, análisis más cultural y lógico. Identificar los elementos que constituyen la obra y crear una conexión. Utiliza el significado.

3. Iconológico, donde encontraremos el significado más profundo de la obra y su contenido. Este es de gran complejidad y hace falta situar a la obra en contexto cultural, histórico, económico y social determinado. El sentido profundo.

En concreto, cuando se habla de una adaptación del método, se hace para advertir que, si bien el nivel iconográfico de Panofsky aspira a crear conexiones y significados culturales y para ello sí recurre a las figuras retóricas, lo que se buscaba acá era solo dar énfasis en la detección de figuras retóricas, dejando las conexiones y significados para el tercer análisis. Es decir, se simplificó el segundo nivel a solo una detección de figuras retóricas evidentes. En resumen, lo que se hizo fue:

1. Un análisis comparable al nivel pre-iconográfico de Panofsky, donde se procedió a describir los elementos presentes, los colores y el ordenamiento de los planos.

2. Un segundo análisis enfocado solo a la detección de figuras retóricas, donde se esperaba buscar comparaciones explícitas, metáforas, alegorías, hipérboles, etc.

3. Un tercer análisis comparable al nivel iconológico de Panofsky, donde se buscó hallar el significado más profundo de la propaganda, atendiendo fuertemente al contexto cultural, histórico, económico y social determinado en el que está inscrita la imagen.

Además, es menester señalar que el tercer análisis (homologable al nivel iconológico de Panofsky) y toda la discusión que de él se desprende y elabora, fue condensado en un solo apartado que agrupa la información de las cinco imágenes. Esta decisión fue tomada en base a que, respondiendo todas al mismo contexto (campañas políticas de un mismo periodo contra el alcoholismo en la Unión Soviética) y presentando una importante homogeneidad en su elaboración, existía una alta posibilidad de que adoptaran significados similares, donde lo cultural, lo histórico, lo económico y lo social serían denominadores comunes en cada una de ellas. Por lo que se optó a hacer un análisis del significado profundo de la cartelería política contra el alcoholismo en general, y no una por una. Esto, además, es la base para la discusión final.

Por otra parte, los cinco carteles sometidos a reflexión fueron ubicados en distintos lugares de la red, tales como registros históricos o colecciones aficionadas. ${ }^{41}$ Fueron elegidas estas cinco imágenes y no otras basado en tres simples criterios: 1) que guardaran información relevante de su elaboración (técnica, género, autor y fecha); 2) que refieran a un periodo entre la revolución de 1917 y el fin de la URSS y 3) que por una parte pudiera tener la capacidad de traducir todo lo escrito presente en el cartel (se eliminaron carteles cuya tipografía fuese ilegible), y por otra parte, que pudiera haber certeza traduciendo- que la información escrita presente en la imagen tuviera coherencia con la ilustración. ${ }^{42}$

Posteriormente, se procedió a la elaboración de párrafos breves que agruparan la información por nivel de análisis. De esta forma, se puede tener un panorama claro y ordenado de toda la información

\footnotetext{
${ }^{41}$ Principalmente fueron extraídas de: http://redavantgarde.com/. Otras fuentes utilizadas fueron: https://es.gizmodo.com/de-la-politica-al-arte-32-grandes-carteles-de-propagan-1465107041. y https://magnet.xataka.com/nuestro-tsundoku/43-ejemplos-de-carteleria-sovietica-que-hicieron-de-la-propaganda-un-arteinsuperable.

42 Este tercer criterio estaba pensado para evitar utilizar imágenes que pudieran parecer atingentes, pero que su parte escrita señale otro contexto. Esto llevó a la necesidad de encontrar una manera confiable de traducir los textos ilustrados en carteles con tipografías no necesariamente clásicas, sino que, en ocasiones, cercanas incluso a la caricatura. Por lo que la traducción se llevó a cabo mediante una herramienta digital que permite escribir manualmente cada caracter, aunque sea una tipografía fuera de lo común, para así dar con la traducción más confiable posible.
} 
extraída de los carteles que permita elaborar conclusiones a partir de las imágenes mismas. Por temas de espacio, los carteles van anexados en la parte final del documento.

Tabla 1

\section{Análisis}

Ficha técnica

\begin{tabular}{|c|c|c|c|c|}
\hline Títulos de carteles & Autor & Fecha & Estilo/género & Técnica \\
\hline "No bebas, papá" & Bulanov, D. & 1929 & Fotomontaje & Litografía tricolor \\
\hline $\begin{array}{l}\text { "Quédate, es la última } \\
\text { advertencia" }\end{array}$ & $\begin{array}{l}\text { Sokolov- } \\
\text { Skalya, P. }\end{array}$ & 1929 & Dibujo animado & Litografía Multicolor \\
\hline $\begin{array}{l}\text { "Y dicen que nosotros } \\
\text { somos los cerdos" }\end{array}$ & Mosin, A. G. & 1958 & Dibujo animado & Impresión offset \\
\hline "Un fuerte apego" & Kukryniksy* & 1959 & Dibujo animado & Impresión offset \\
\hline $\begin{array}{l}\text { "No te arruines a ti } \\
\text { mismo" }\end{array}$ & Briskin, V.M. & 1963 & Vanguardista & \\
\hline
\end{tabular}

Nota. Cada cartel se encuentra junto a su análisis en el orden acá establecido.

* Kukryniksy fue un grupo de tres caricaturistas de la Unión Soviética. Su nombre es una combinación de tres dibujantes: Mijaíl Kupriyánov, Porfiri Krylov, y Nikolái Aleksándro

\section{Bulanov, D. (1929). “No bebas, papá”.}

\section{Nivel pre-iconográfico de Panofsky:}

Fondo negro opaco; en primer plano un niño con botines, pantalones cortos, chaleco y por sobre un delantal típico de la época y la cultura. Su brazo, en altura media, no completamente erguido. También

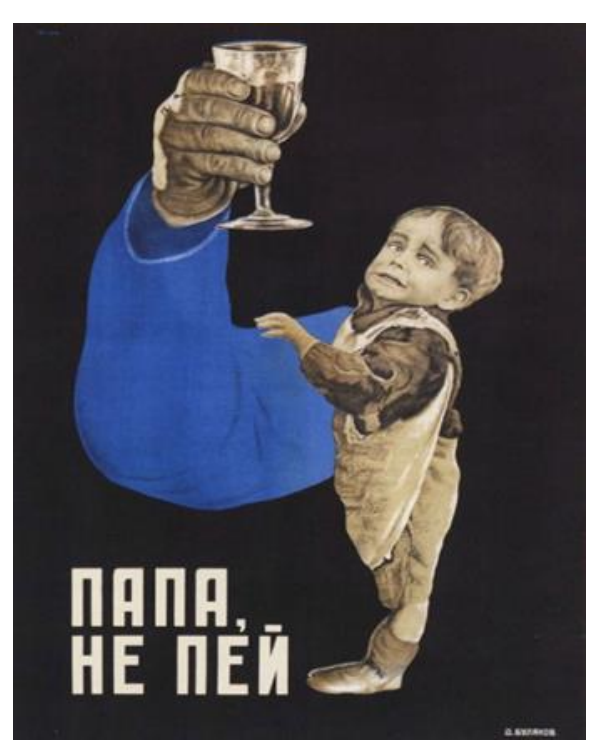

en primer plano, pero del lado inferior izquierdo, la inscripción "No bebas, papá". En un segundo plano aparece un brazo adulto, de grandes proporciones, con una manga azul y que sostiene una copa con algún tipo de bebestible que ocupa prácticamente toda la mitad superior de la imagen.

\section{Detección de figuras retóricas}

Hipérbole en el brazo exageradamente grande en proporción al niño: su disposición (detrás y a la vez sobre el niño), más su tamaño dan indicios de que es algo abrumador, que atormenta por su grandeza. Apóstrofe: la expresión facial del niño, sus cejas juntas y levantadas al medio, su boca tensa y mirada de reojo, denotan una clara exclamación que va dirigida a alguien. Sinécdoque: el brazo representa la parte por el todo. Basta su presencia para entender que el eventual personaje detrás es su padre y además consumidor. 


\section{2.- Sokolov-Skalya, P. (1929). “Quédate, es la última advertencia”.}

\section{Nivel pre-iconográfico de Panofsky}

Imagen con un pequeño margen de marco, de fondo negro opaco con luz enfocada en la parte

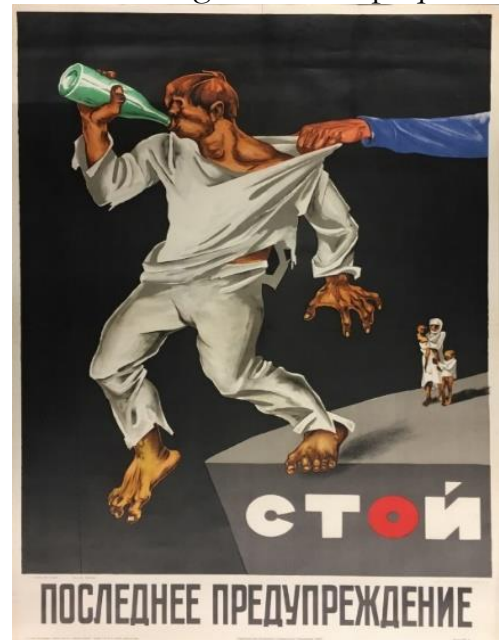
inferior; en primer plano y ocupando gran parte del cartel, se muestra a un hombre descalzo, vestido completamente de blanco, ropa descuidada y rota; el hombre está sosteniendo una botella de color verde claro con su mano derecha mientras bebe de ella, desde el otro lado, una mano con manga azul en el antebrazo lo sostiene de la camiseta para que no caiga por un barranco que se aprecia en la parte inferior de la imagen; detrás de él, en segundo plano, y en tamaño muy disminuido se aprecian tres personas también vestidas de blanco, la figura más pequeña está sobre los brazos de una mujer que además porta un velo sobre la cabeza, mientras que del otro lado, otra persona que aparenta ser un niño y que no porta pantalones, se aferra a ella; la parte escrita se concentra en el extremo inferior y dice en ruso "quédate, es la última advertencia".

\section{Detección de figuras retóricas}

El brazo que sostiene al hombre es, por una parte, una alegoría que intenta representar figuradamente al Estado como el responsable de salvar al personaje y, por otra parte, encarna también una sinécdoque que intenta representar la parte por el todo. Basta su presencia para entender que es todo el aparato estatal quien lo está sosteniendo y dando una última oportunidad. Por lo mismo, se puede interpretar también como una prosopopeya, donde se le atribuye una actitud humana al Estado; la parte escrita ("quédate, es la última oportunidad") representa una sentencia. Mientras que el barranco del que está por caer el hombre, se presenta como metáfora de la perdición a la que lleva el alcohol; se aprecia también una bipérbole en el tamaño exageradamente pequeño de las tres personas detrás, para producir un efecto de lejanía que, además, es una metáfora de que está dejando atrás a su familia. La botella, por otra parte, sin tener ningún rastro distintivo, se entiende como metáfora del alcohol.

\section{Mosin, A.G. (1958). "Y dicen que nosotros somos los cerdos".}

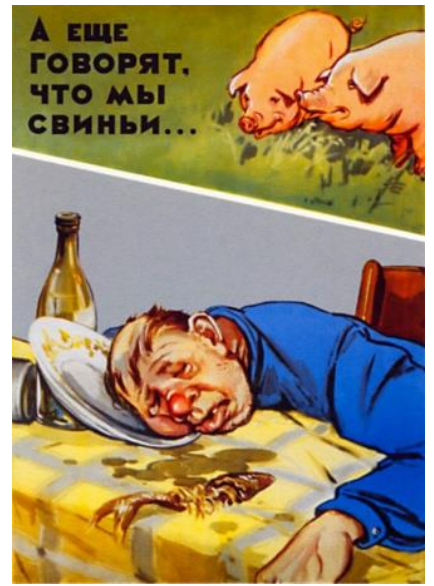

\section{Nivel pre-iconográfico de Panofsky}

Imagen a color, donde predomina el verde del pasto, el gris del fondo, el amarillo del mantel y el azul de la camisa; en un primer plano y en la parte inferior del cartel, se aprecia a un hombre volcado sobre una mesa, con la cabeza sobre un plato sucio, con los ojos cerrados y la boca semi abierta, viste una camisa azul de mangas largas. La mesa sobre la cual está apoyando su cabeza y brazo izquierdo está cubierta de un mantel amarillo con líneas verticales y horizontales de color gris, se ve evidentemente sucio, con restos líquidos derramados que forman manchas. El plato sobre el que descansa está sucio y arrimado sobre otros objetos que no se aprecian, sin embargo, detrás se evidencia una botella de color amarilla; en un segundo plano detrás de esta escena y en la parte superior, se aprecian dos cerdos sobre el pasto que apuntan su mirada hacia el hombre y hacia un extremo. Al lado izquierdo de la imagen, a un costado de los cerdos, se lee una inscripción de letras negras que indica "y dicen que nosotros somos los cerdos". 


\section{Detección de figuras retóricas}

La presencia de los cerdos, sumada a la inscripción "y dicen que nosotros somos los cerdos", representa, por una parte, una metáfora a la 'inmundicia' que simbolizan popularmente estos animales, esta vez atribuida al hombre. Y, por otra parte, representan una clara personificación en donde los animales comentan entre ellos lo que ven; en una delgada línea entre la metáfora y el símbolo, la nariz enrojecida de la persona representa el estado de embriaguez, mientras que su estado: ojos cerrados, boca semi abierta, tumbado sobre un plato sucio y al lado de una botella, refuerzan esta idea. Por lo mismo, la botella presenta una metáfora al alcohol.

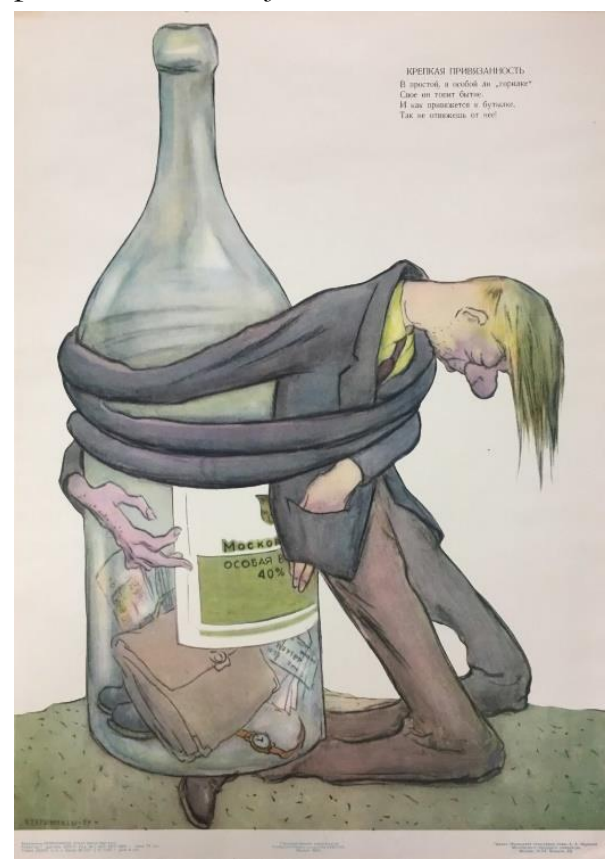

\section{Kukrynisky. (1959). "un fuerte apego".}

\section{Nivel pre-iconográfico de Panofsky}

Imagen con gran parte del fondo en un color entre gris y blanco opaco. En primer plano, ocupando gran parte de la imagen y en el centro del espacio, se aprecie un hombre adulto de aspecto muy delgado, especialmente en sus dedos y piernas, viste un traje de pantalones café y chaqueta gris, camisa amarilla y corbata café. Su cabeza y mirada están inclinadas hacia abajo; sus brazos, largos, dan vuelta a una gran botella transparente que además está sobre sus pies. En el interior de la botella se ven objetos domésticos como un reloj, la punta de unos zapatos, un bolso y algunos papeles; en el extremo superior derecho, con letras muy pequeñas y en alfabeto ruso, una inscripción que dice "Un fuerte apego. En simple, en un "Horilka" especial él ahoga su ser. ¡Y de qué manera! apegándose a la botella, jasí que no la desaten!’. 43

\section{Detección de figuras retóricas}

Hipérbole en el tamaño exageradamente grande de la botella, siendo incluso superior a la figura del hombre. La misma botella presenta un hipérbaton, al alterar el orden lógico con cosas que, por sentido común, no deberían estar dentro de ella (también podría ser un anacoluto); los brazos, de extrema largura y flexibilidad, también representar una hipérbole. Mientras que, al estar enrollados varias veces alrededor de la botella, que por su inscripción se entiende que es de horilka (un tipo de vodka), se compone la metáfora de que el hombre no puede ni quiere dejar el alcohol. Así mismo, al haber objetos domésticos que van acorde a la ropa del hombre, se crea la metáfora de que toda su vida está en esa botella, o que es lo único que tiene y por ello se aferra así.

\footnotetext{
${ }^{43}$ Esta inscripción corresponde a un pequeño verso de la poeta soviética Emil Meek.

* Horilka es un derivado del vodka elaborado en Ucrania, muy popular en las calles del Moscú soviético.
} 


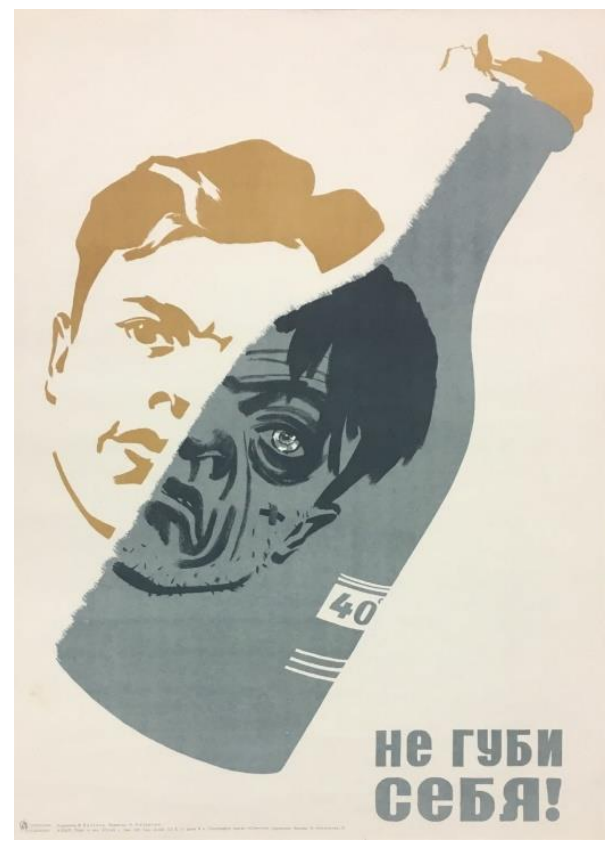

5. Briskin, V.M. (1963). “No te arruines a ti mismo". Nivel pre-iconográfico de Panofsky

Imagen de pocos elementos, de fondo rosado claro; en primer plano, en el extremo inferior derecho, aparece una inscripción en ruso que dice "no te arruines a ti mismo". También en primer plano y ubicada en diagonal de forma tal que atraviesa desde el extremo inferior izquierdo hasta el extremo superior derecho, se ve la figura de una botella transparente, que deja ver una pequeña etiqueta con el número 40 y algunas líneas horizontales, tiene también una tapa o corcho; en segundo plano y detrás de la botella, cargada hacia el lado izquierdo de la imagen y con una leve inclinación, se aprecia un rostro humano, de un hombre, pelo corto y rasgos marcados, donde una parte de la cara se ve a través de la botella.

\section{Detección de figuras retóricas}

La simpleza de la imagen, en términos de contenidos visuales expuestos en ella (inscripción, botella y rostro) genera un juego entre dos figuras retóricas que adquieren toda la importancia del cartel. La botella, que se entiende por el contexto que es de alcohol, logra mostrar a través de ella una parte del rostro que difiere totalmente de la otra mitad, la primera se muestra como una cara normal, de pelo ordenado y sin nada fuera de lo común, mientras que la mitad que se ve tras la botella, muestra un rostro desaseado, desordenado, arrugado, con una cicatriz en la mejilla y un ojo considerablemente demacrado, es de decir, estamos ante una comparación explícita de ambas partes del rostro. Sin embargo, esta comparación sólo adquiere sentido a través de la metáfora de que, tras el alcohol (tras la botella), sólo hay perjuicios y repercusiones negativas, esta idea se refuerza con la inscripción de "no te arruines a ti mismo", posicionando al alcohol como el responsable de arruinarse, devastarse, demacrarse a uno mismo, intentando transmitir cierta monstruosidad en el rostro.

\section{Análisis de nivel iconológico de los cinco carteles}

Tal como lo señala el método que se está empleando, este nivel busca hallar un significado más profundo de las imágenes, para ello, el contexto cultural, histórico, económico y social que se pueda desprender del marco teórico será fundamental.

Se puede observar cómo es frecuente recurrir a la figura de los niños y familiares directos en parte de la cartelería seleccionada. En el primer cartel (Bulanov, 1929), con una clara muestra de angustia, con sus cejas y boca tensa el pequeño pareciera suplicar a su padre que no beba más, levantando temeroso su mano ante la inmensidad que supone el brazo adulto tomando la copa; mientras que en el segundo (Sokolov-Skalya, 1929), lejanos, descuidados y mirando con impotencia, aparecen quienes serían la familia del hombre que 'ciego' por el alcohol camina directo al precipicio, a la perdición, al olvido, dejando atrás a una familia con 'necesidades'. Esta idea de presentar el efecto negativo del alcohol aparejado a una familia detrás sufriendo tiene una cercanía enorme con el principio número 6 de manipulación de masas: utilizar el aspecto emocional mucho más que la reflexión. Pero dentro de esos aspectos emocionales, el principio número 7 pareciera calzar aún mejor: promover la autoculpabilidad. Estas dos propagandas parecieran reforzar la idea de buscar hacer sentir responsable, pero sobre todo culpable al consumidor de alcohol de todos los males que su conducta le transmite a su familia e hijos, quienes sufren por él.

Modalidad de publicación continua / Continuous publication modality 
Por otra parte, el resto de los carteles parecieran transmitir la idea de que se deja de ser uno mismo consumiendo alcohol. La tercera imagen (Mosin, 1958), claramente compara e ironiza con la figura de dos cerdos, quienes se jactan de ser incluso más aseado e higiénico que el alcohólico, llevando al consumidor a pensarse incluso 'menos que un cerdo'; el cuarto cartel (Kukryniksy, 1959) muestra un cuerpo débil, aferrado a la nada, cabizbajo, sin energía más que para no soltar la botella, en donde además se resume toda su vida, su poca vida; el último cartel (Briskin, 1963), quizás el más explícito en la idea de dejar de ser uno mismo, muestra la monstruosidad aparejada al consumo de alcohol, monstruosidad que además afecta el rostro, deformándolo, haciéndolo irreconocible, demacrándolo.

Estos carteles evidentemente forman parte de la llamada propaganda emocional y queda claro cómo intentan empujar e influir sobre los sentidos, especialmente sobre las emociones, provocando o intentando provocar un remezón en las estructuras emotivas de las personas, ya sea mediante la utilización de la culpa frecuentemente asociada al malestar de la familia, como a la utilización de la vergüenza, aparejada con una evidente deformación o transformación de quien se es, por alguien e incluso por algo mucho peor.

Lo que probablemente buscaba este tipo de propaganda es lo que históricamente ha buscado el gran país, disminuir el consumo de alcohol en sus ciudadanos, especialmente en hombres. Tarea que al parecer ha sido causante de las más contradictorias políticas públicas en la historia de Rusia. En el extenso periodo de la URSS, como indican estos insuficientes pero muy ilustradores carteles seleccionados, se recurría a la propaganda emocional para intentar influir en esta conducta, pues, así como su historia contribuyó a solidificar este mal, debía al menos preocuparse por remediar sus efectos.

\section{Discusión}

Las limitaciones de este estudio son evidentes. No se trata tanto de un sólido intento por establecer una única concepción, o la mejor de las interpretaciones acerca de la cartelería soviética, como sí de un primer paso en una dirección poco (o nulamente) explorada con anterioridad, y en tanto tal, susceptible a errores y sensible a mejoras. En esa línea, surge un primer elemento el cual fue ignorado teórica y metodológicamente: la amplitud en el rango temporal de los carteles seleccionados. Si bien se enmarca en el periodo que comprende la totalidad de la URSS, visto en detalle responde a contextos bastantes distintos. En efecto, tanto el cartel de Bulanov (1929) como el de Sokolov-Skalya (1929) corresponden al periodo estalinista temprano, mientras que los de Mosin (1958), Kukryniksy (1959) y Briskin (1963), se insertan en el periodo de desestalinización, es decir, en pleno proceso por contrarrestar el culto y exceso de poder. Además, estos últimos tres carteles se desarrollan en medio de la Guerra Fría. Cabría preguntarse si altera en algo la urgencia estatal porque sus ciudadanos dejen el alcohol el hecho de que ya no solo se juegue la reestructuración de la patria, sino que, en plena Guerra Fría, lo que está en juego, en términos geopolíticos, es mucho mayor. Así también, se empieza a perfilar otra pregunta que será clave en futuros estudios y que merece ser abordada en extenso: ¿cuál es la relación efectiva entre ideología y biopolítica?

Un segundo elemento emerge exigiendo mayor profundización. La inminente generalización que se podría desprender del análisis de solo cinco carteles trae aparejada consigo la necesidad de ampliar el debate a otros contextos socialistas que permitan comparar, o al menos debatir, en qué términos se hace realmente posible hablar de una gestión biopolítica del asunto. 
Exploraciones tan someras como apresuradas parecen mostrar escenarios disímiles. Por ejemplo, en el Chile socialista de Salvador Allende (1970-1973) a pesar de que la lucha contra el alcoholismo era una de las 40 medidas del gobierno, la prolífera creación de cartelería política poco abordó este tema. Así lo demuestra el trabajo de Mauricio Vico ${ }^{44}$, quien recopiló uno de los catálogos más completos de la cartelería política de la izquierda chilena durante el gobierno de Allende, y que asegura que solo existió un cartel que hizo referencia al alcoholismo. En éste se aprecia una familia nuclear clásica 'sosteniendo' el techo de un hogar, felizmente apegados unos a otros. Mientras que en la parte superior izquierda se lee "¿bebiendo soluciona sus problemas? El alcohol es miseria $y$ subdesarrollo". En un mensaje que parece contraponer una vida buena al presente del alcohol, del cual no se hace referencia gráfica.

Tal como sucede en términos generales con este trabajo, un solo cartel del gobierno popular no permite extraer conclusiones de cómo se abordó este asunto público. Sin embargo, en un documento titulado Con Allende y por la Patria, Plataforma de gobierno del Partido de la Unidad Popular, que comprende el llamado 'programa de gobierno', se aprecia que la propuesta número dieciocho alude al tema del alcohol con la siguiente promesa:

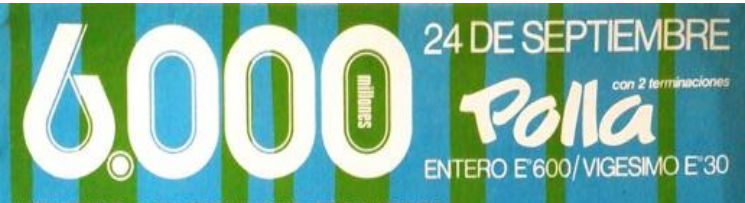
¿BEBIENDO SOLUCIONA SUS PROBLEMAS?.
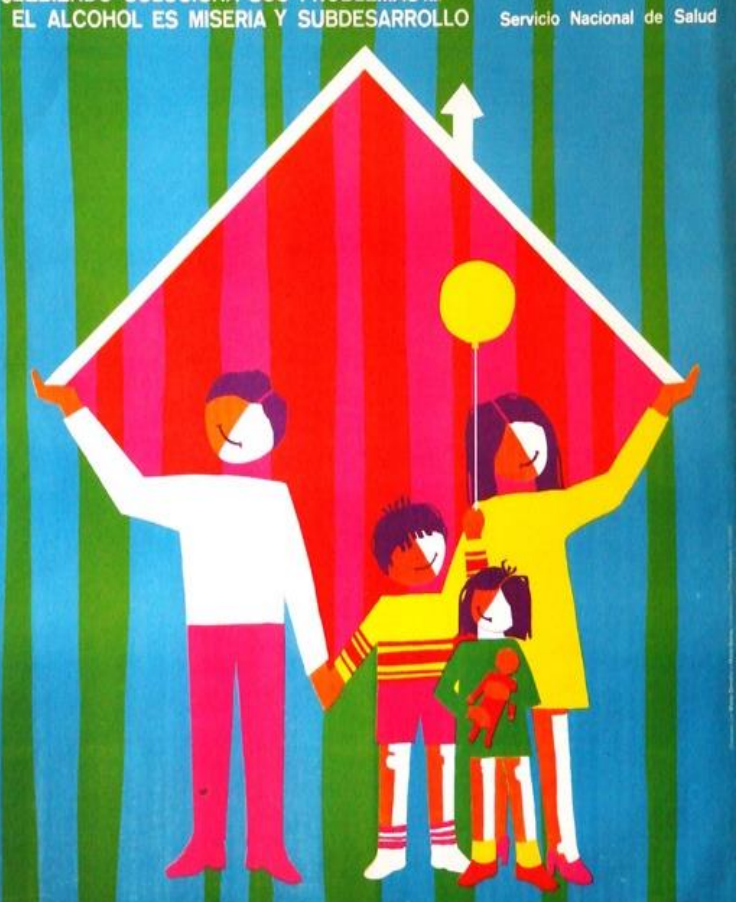

BENEFICIARIO:CORPORACION DE SERVICIOS HABITACIONALES

"Combatiremos el alcoholismo no por los medios represivos, sino por una vida mejor y erradicaremos el clandestinaje". ${ }^{45}$ Lo que ya da pistas de un tratamiento completamente distinto al mismo problema aquí analizado. En la misma línea, en un discurso de Salvador Allende con motivo de la celebración del primer año de gobierno, se vuelve a apreciar que el interés estatal parece estar lejos de la represión y prohibición total:

Debemos preocuparnos de los enfermos que son los alcohólicos. Yo les he dicho que una de las enfermedades más graves de Chile es el alcoholismo. Yo les he dicho que en el Gobierno del Pueblo se tomará menos y mejor, y eso lo vamos a cumplir también, compañeros. ${ }^{46}$

\footnotetext{
44 Mauricio Vico, El Cartel Político, Social y Cultural de la izquierda chilena en el Gobierno de la Unidad Popular: 1970-1973 (Tesis Doctoral). Universidad de Barcelona, Barcelona, 2015

45 Vico, op. cit., p. 470.

46 Discurso completo disponible en: http://www.abacq.net/imagineria/discur4.htm
} 
Otro gobierno socialista, como es el caso cubano, podría presentar mayores similitudes al soviético por su histórica importancia a nivel mundial en la producción de ron derivado de la caña de azúcar. Sin embargo, estudios como el de Gonzále ${ }^{47}$ muestran los grandes resultados que ha tenido la política rehabilitadora, y no prohibitiva, durante los últimos 40 años, siempre guiada, dice el autor, por la filosofía marxistaleninista y una alta exigencia espiritual, ética y bumanista. Asimismo, un cartel publicado por el órgano oficial del comité central del Partido Comunista de Cuba (Granma) ${ }^{48}$, si bien juega con la imagen de un disco pare y una botella en su interior, como queriendo decir "pare con el alcohol", no hace referencia a ninguna medida represiva, ni menos hace uso de emociones como la culpa o la vergüenza para gestionar la vida de sus ciudadanos.

Por otro lado, la Guerra Civil Española de 1936 fue escenario de una gran actividad propagandística. Así, la ya consolidada Confederación Nacional del Trabajo (CNT), agrupación de sindicatos autónomos de corte

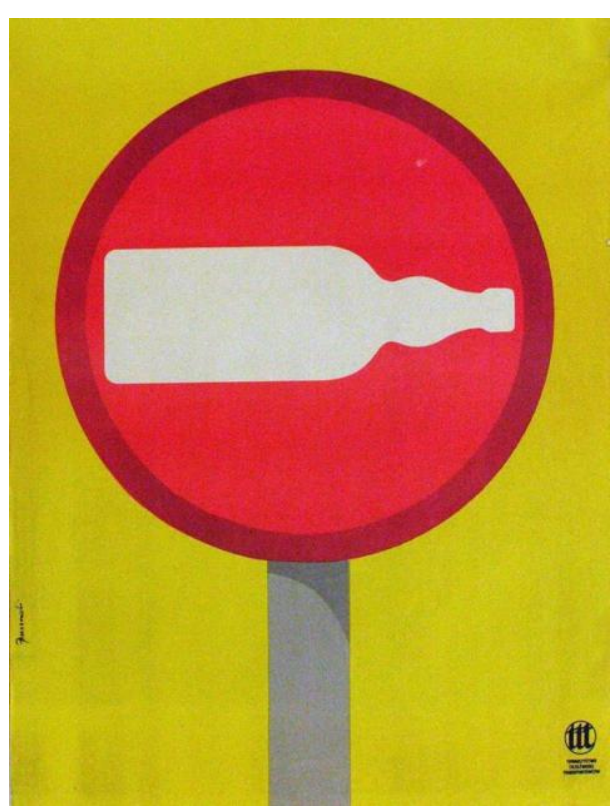
anarcosindicalista, nos dejó cartelería antialcohol que nos empuja a continuar con esta área de estudios, pues sus expresiones gráficas van explícitamente en la misma línea soviética, es decir, apelando fuertemente a emociones como la culpa y la vergüenza, siendo incluso más directas en su trato con los obreros a los que intentaba convencer de alejarse del alcohol en medio de la lucha política. Vemos, por ejemplo, que eran tratados de parásitos que merecían ser eliminados e ilustrados como personas demacradas ${ }^{49}$.
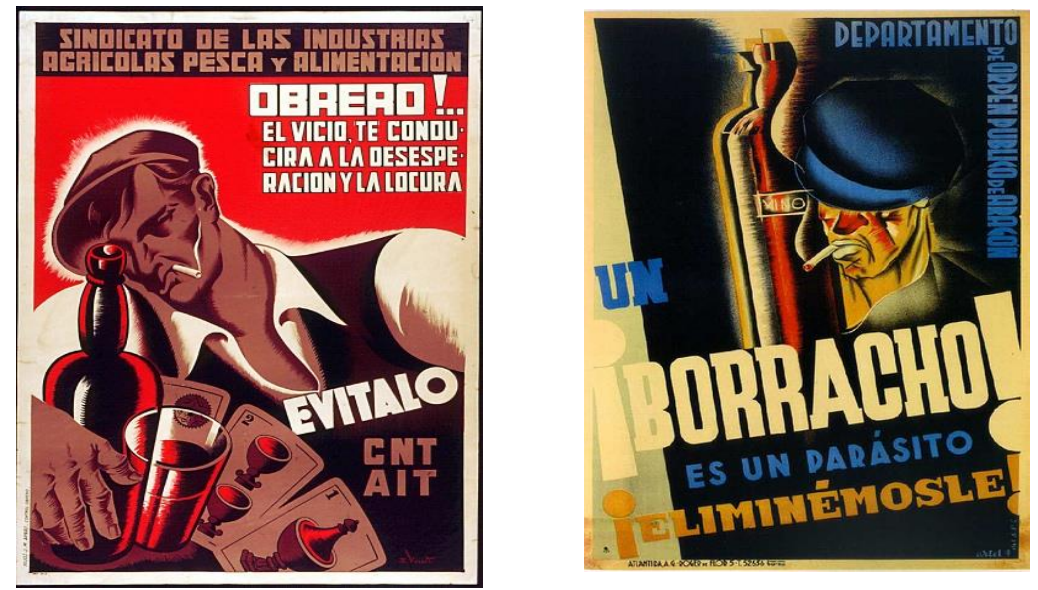

Así también se puede traer al debate el caso Nazi. Lo que el alcohol fue para la URSS, el tabaco lo fue para los Alemanes y su excelsa cartelería política pareciera conducir la lucha antitabaco con la misma vehemencia soviética y con el mismo objetivo aparentemente puesto en generar sentimientos de

\footnotetext{
47 Ricardo González, La atención integral al alcoholismo: experiencia cubana, Revista Cubana de Medicina, 2008, Vol 47, No. (2), p.112.

48 Disponible en: http://www.granma.cu/salud/2014-06-25/una-vacuna-contra-el-alcoholismo?page=2

49 Ambos carteles disponibles en: https://serhistorico.net/2018/07/19/campanas-leyes-y-movimientos-contra-el-consumo-dealcohol-s-xix-xx/
} 
humillación y vergüenza y, en última instancia, gestionar de una manera determinada la vida de las personas.

Estas apresuradas comparaciones más que cerrar respuestas, generan preguntas que solo llevan a un camino: la necesidad de continuar profundizando la discusión aquí abierta. ¿Cuál es, finalmente, la relación entre ideología y biopolítica?, ¿supera acaso los marcos capitalistas neoliberales en los que fuera inicialmente pensada?, ¿pueden los análisis biopolíticos nutrirse de metódicas como la propuesta? Las preguntas son variadas y las respuestas irán llegando mientras se sigan explorando y tensionando. Lo que concierne a este estudio exploratorio, parece haber marcado cierto recorrido que vale la pena explotar.

\section{Conclusiones}

Luego del análisis iconográfico aplicado a la cartelería, se puede sostener que lo que buscaba este tipo de propaganda política era la producción y gestión de ciertas emociones en el cuerpo social, lo que traza inevitablemente relaciones entre lo social y lo emocional del ser humano en una realidad social determinada. Si se piensan las emociones que vive un sujeto que interactúa en un cuerpo social como "prescripciones creadas por dicho sistema social" o como "parte del repertorio de la expectación sociocultural", 50 se establece inmediatamente un valor funcional y una evidente importancia políticosocial al hecho de sentir o no una determinada emoción, pues son maneras de reforzar conductas que políticamente son deseadas y rechazar las que no lo son. En este caso, la conducta deseada es dejar el alcohol, por lo que el Estado prescribe que el cuerpo social sienta culpa y vergüenza y las ligue (mediante el efecto de la propaganda) al consumo, de esta forma se potencia el alejarse del alcohol y por ende se refuerza, aunque no por acción directa, el no beber.

En el caso de la culpa, si asumimos, como lo hace Dubiel, que se origina a partir de la experiencia de una no-coincidencia entre los parámetros morales que hemos internalizado y la vida que llevamos ${ }^{51}$, entonces no es desafortunado plantear que la cartelería política buscaba, de hecho, acrecentar y profundizar esa no-coincidencia a los parámetros que moralmente espera el Estado de sus ciudadanos. Así también, se habla de culpa cuando no estamos dispuestos a asumir la responsabilidad por el mal que hemos causado o que ha ocurrido en nuestro nombre ${ }^{52}$, y tal como vimos, los carteles son explícitos en demostrar que mediante el alcohol se causa un mal, una injusticia, una imprudencia que suele recaer en la familia, apuntando a generar culpa por su evidente sufrimiento y la negación o rechazo a incorporar la responsabilidad de quien bebe.

Por otra parte, no es extraño que la vergüenza esté vinculada al sí mismo, como vimos en la cartelería lo que se busca es transmitir la idea de que mediante el alcohol se deja de ser uno mismo, especialmente en cuanto a la dimensión corporal, a la imagen de sí mismo (cerdos, cara demacrada, extrema delgadez). Hilando fino, en los distintos contextos donde uno puede sentir vergüenza, la razón siempre está unida a que el hecho constitutivo lo remite siempre, de una u otra forma, a sí mismo. Es la manera de percibir al sí mismo el que está en juego cuando se siente vergüenza. La preocupación por sí mismo, la inquietud de sí y el conocerse a sí mismo, son, de hecho, los principios fundamentales de las tecnologías del yo por medio de las cuales un sujeto se transforma a sí mismo, y en esto Foucault ${ }^{53}$ es claro. En definitiva, estaríamos hablando de un contexto sociocultural e histórico-político que termina constituyendo o forjando toda posibilidad, todo límite o frontera entre las cuales circularán y se expresarán las emociones que el cuerpo social puede sentir. Provocando una necesidad de gestionarlas por obra de uno mismo (tecnologías del yo). Sin embargo, si consideramos que las emociones son también

\footnotetext{
50 Rogerio Luna \& Lucia Mantilla, Desde la sociología de las emociones a la crítica de la Biopolitica. Revista Latinoamericana de Estudios sobre Cuerpo, Emociones y Sociedad, 2017, Vol 9, No (25), p.24-33.

51 Helmut Dubiel, La culpa política, Revista Internacional de Filosofía Política, 1999, No. (14), p.6.

52 Dubiel, op. cit., p.7

${ }^{53}$ Foucault, Tecnologias del yo..., 1990, p.50.
} 
objeto de control político y por ende de instrumentalización racional por parte de organizaciones y grupos dominantes que ejercen el poder desde sus instituciones, como lo fue en la URSS, estaríamos entonces también frente a una tecnología de poder, y por consecuencia, lo que se daría en el contexto soviético de la cartelería revisada sería un proceso de gubernamentalidad, donde, al igual que en sociedades capitalistas, lo que busca el Estado es un control de la vida misma mediante el control político del cuerpo, prescribiendo emociones para evitar que las personas consuman determinada sustancia, es decir, el control es tal que busca intervenir en el hecho mismo de ingerir, absorber, asimilar un determinado producto, el alcohol. En definitiva: biopolitica.

\section{Bibliografía}

\section{Fuentes Impresas}

BURKE, Peter, (Ed.), Formas de hacer historia., Madrid, Alianza Universidad, 1993.

BURKE, Peter, Lo visto y no visto. El uso de las imágenes como documento histórico., Barcelona, Ed. Biblioteca de Bolsillo, 2005.

CHOMSKY, Noam, El miedo a la democracia, Barcelona, España, Crítica, 1992a.

CHOMSKY, Noam, Ilusiones necesarias. Control del pensamiento en las sociedades democráticas. Madrid, España, Ediciones Libertarias, 1992b.

CHOMSKY, Noam, La propaganda y la opinión pública, Barcelona, España, Crítica, 2002.

DOMENACH, Jean-Marie, La propaganda politica, Paris, Francia, PResses Universitaires de Francc, 1950.

FOUCAULT, Michel, Defender la Sociedad. Curso en el College de France 1975-1976., Buenos Aires Argentina, Fondo de Cultura Económica, 2000.

FOUCAULT, Michel, La voluntad de saber. México DF, México, Siglo XXI, 1996.

FOUCAULT, Michel, Nacimiento de la Biopolitica. Curso en el College de France 1978-1979., Buenos Aires, Argentina, Fondo de Cultura Económica, 2007.

FOUCAULT, Michel, Tecnologías del yo y otros textos afines, Buenos Aires, Argentina, Ediciones Paidós, 1990.

FOUCAULT, Michel, Vigilar y Castigar. El nacimiento de la prisión, Bueno Aires, Argentina, Siglo XXI Editores, 1976.

HITLER, Adolf, Mi lucha, Santiago, Galas Ediciones, 2012.

JARA, Lillyan \& ROJAS, Pedro, La propaganda politica. Santiago, Chile, Editorial Universitaria, 1956, 208 pgs.

MILLAR, James, Encyclopedia of Russian History. Vol III. New York, EE.UU, Board Editorial, 2004. 
PANOFSKY, Erwin, El significado en las artes visuales. Madrid, España: Alianza Forma, 1979.

\section{Fuentes Digitales}

ALLENDE, Salvador, "Un año de Gobierno Popular" discurso público en el Estadio Nacional, 4 de noviembre de 1971.

DUBIEL, Helmut, La culpa política, Revista Internacional de Filosofía Política, 1999, No. (14), p. 5-14.

FOUCAULT, Michel, El sujeto y el poder, Revista Mexicana de Sociología, 1988, Vol 50, No. (3), p.3-20.

GONZÁLEZ, Ricardo, La atención integral al alcoholismo: experiencia cubana, Revista Cubana de Medicina, 2008, Vol 47, No. (2), p.1-12.

JULIAN, Inmaculada, La propaganda Rusa en el periodo 1917-192, Revista del departamento d'Historia de l’Arte, 1986, No. (12), p.223-233

LUNA, Rogerio \& MANTILLA, Lucia, Desde la sociologia de las emociones a la crítica de la Biopolítica. Revista Latinoamericana de Estudios sobre Cuerpo, Emociones y Sociedad, 2017, Vol 9, No (25), p.24-33.

LUTHMEIER, Guilherme, A propaganda política soviética. Uma Análise de dez cartazes de 1917 a 1945, (Tesis

Doctoral), Universidade Federal Do Rio Grande do Sul, Porto Alegre, 2010.

MARTÍNEZ, Jorge \& GUARÍN, Yudi, Aproximación a una cartografía conceptual de la biopolitica. Revista Latinoamericana de Bioética, 2014, vol 14, No. 2, p. 102.

MARTÍNEZ, Jorge, El cuerpo como nueva superficie de inscripción de la política: Michel Foucault y la biopolitica., Revista Sociología y Tecnología, 2017, Vol 8, No (1), p.27-42.

PETRINO, Jessica, La propaganda del movimiento bolchevique. Revista Relaciones Internacionales, 2016, No.(51), p. 1-9.

REY, Juan, Publicidad y religión. Semejanzas y diferencias entre el discurso publicitario y el discurso católico. Trípodos, 2006, Vol 1, No (18), p. 65-94.

ROCA, Lourdes, La imagen como fuente: una construcción de la investigación social. Revista Razón y Palabra, 2004, No. (37), p. x-x.

RUIZ, Pilar, El nacimiento del cartel político y su relación con las vanguardias. Questiones Publicitarias, 1997, No. (6), p.63-72.

SÁNCHEZ, Ana, La propaganda "cultural" soviética en la Segunda Guerra Mundial: los casos del comité para los asuntos de las artes y literatúrnaya gazeta (Tesis Doctorah). Universidad Pompeu Fabra, Barcelona, 2016.

SAURA, Geo \& LUENGO, Julian, Biopolitica y educación. medición, estandarización, regularización poblacional, Teor. educ., 2015, Vol 27, N(2), p. 115-135.

VICO, Mauricio, El Cartel Politico, Social y Cultural de la izquierda cbilena en el Gobierno de la Unidad Popular: 1970-1973 (Tesis Doctoral). Universidad de Barcelona, Barcelona, 2015.

Modalidad de publicación continua / Continuous publication modality 